\title{
A Study on Occupancy and Compressive Strength of Concrete with Produced Injection Method
}

\author{
Cevdet Emin Ekinci and Omer Kelesoglu \\ Department of Civil Engineering, Technology Faculty, Firat University, 23119 Elazig, Turkey \\ Correspondence should be addressed to Omer Kelesoglu; okelesoglu@firat.edu.tr
}

Received 28 March 2014; Revised 7 May 2014; Accepted 11 May 2014; Published 28 May 2014

Academic Editor: Ying Li

Copyright (C) 2014 C. E. Ekinci and O. Kelesoglu. This is an open access article distributed under the Creative Commons Attribution License, which permits unrestricted use, distribution, and reproduction in any medium, provided the original work is properly cited.

\begin{abstract}
Concrete is a composite construction material made primarily of aggregate, cement, and water. Fresh concrete must have certain features. These are shown in durability, workability, compressive strength, flexural strength, shrinkage, impact resistance, wear, and so forth. In this study, compressive strength, erosion, and attrition behavior of concrete with silica fume additive produced by injection method were researched. Concrete with high occupancy is produced with injection. Use of more than $10 \%$ silica fume increases the fresh concrete's need for mixed water significantly. It was observed that as the ratio of silica fume additive increases, concrete becomes stronger against compression, erosion, and attrition.
\end{abstract}

\section{Introduction}

Concrete is produced by a combination of aggregate, cement, and water in certain ratios. Injection is a base improvement method that is applied by injecting a mixture under pressure to the porosities in the rock base or concrete for the purpose of increasing the slide resistance or increasing the impermeability of the medium. By bonding the particles together in this way, resistance to shape changes is increased. The strength of the injected base is related to properties of the base and injection mixture.

The most analyzed and in a sense the most important mechanical property of concrete is its compressive strength. Compressive strength is directly proportional to concrete's other positive qualities. Concrete with high compressive strength is occupied, hard, water resistant, unreadable, and resistant to other outside effects. By determining concrete's compressive strength, a general evaluation about concrete's quality can be reached.

According to Bhanja and Sengupta, although concrete mixes are proportioned on the basis of achieving the desired compressive strength at the specified age, tensile strengths often play a vital role in concrete making. In concrete, cracks can propagate very easily in tension, and the cracking of concrete due to its tensile stress being exceeded may cause serviceability and durability problems [1].
There are some factors affecting concrete's compressive strength including component material and properties, occupancy, outside effects, cure, and experimental conditions. High dosage of cement can increase its strength up to a point, although what ultimately determines the resistance is not purely dosage but also S/B and occupancy. In good concrete, occupancy has to be larger than 0.80 . Concrete with high occupancy is expected to have high compressive strength. In the process of hardening, the effects of humidity and temperature on the development of the concrete's compression strength are very significant. Concrete is used in structures that are exposed to high compression stress. There are also types of structures where the concrete is under the effects of stresses besides compression, such as hauling, bending, collision, and erosion. Examples are roads, airports, and dams. Concrete in this structure must have adequate resistance to these additional effects. These applications require selection of appropriate concrete that can resist environmental conditions while also taking various precautions.

For increasing the occupancy of concrete, the methods most often resorted to are the use of low W/C ratio, selection of homogeneous aggregate granulometry, and good compression of fresh concrete. In this study, aside from these methods, the development of concrete's compressive strength, erosion, and attrition resistance was researched by injecting cement 


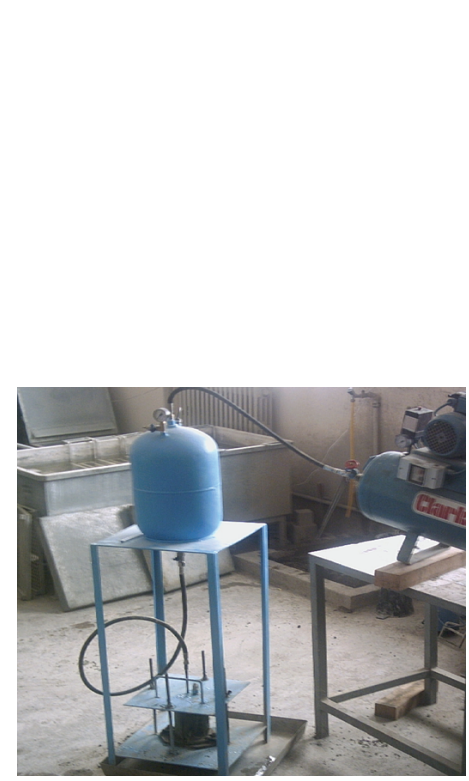

(1) Air compressor

(2) Air output valve

(3) Hydraulic hose

(4) Pressurized air input

(5) Steel injection tank

(6) Manometer

(7) Safety valve

(8) Mixture input tank

(9) Mixture output-control valve

(10) Spiral hydraulic hose

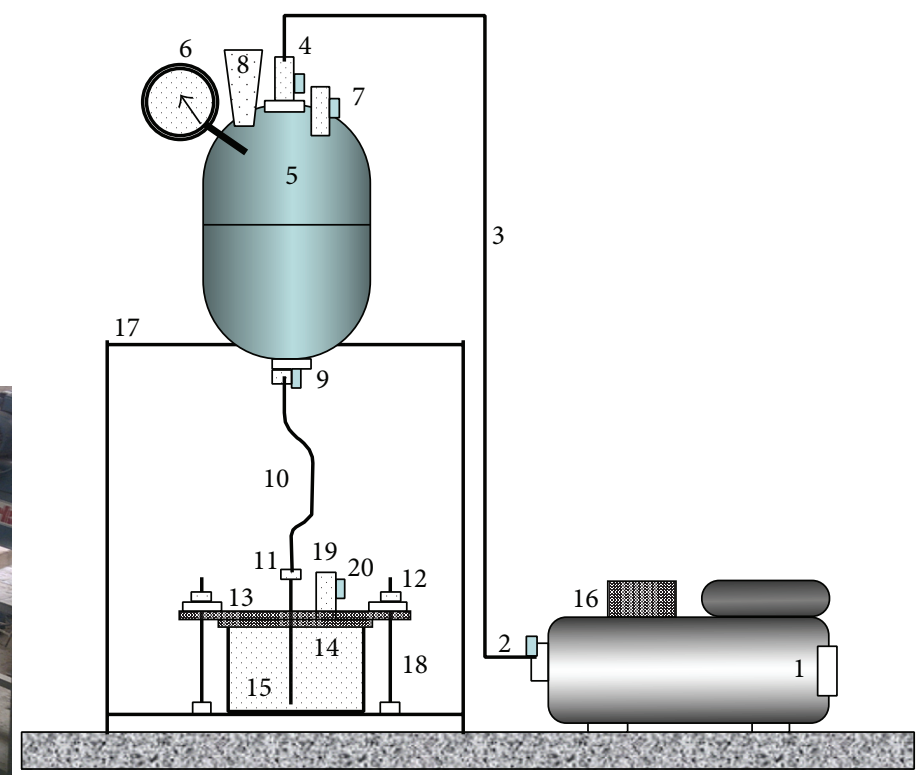

(11) Chrome injection rod

(12) Height adjusted butterfly screw

(13) Cast rigid cap

(14) Gasket

(15) Standard concrete cast

(16) Automatic pressure control system

(17) Safety zone and mount

(18) Steel stud bolt

(19) Air and cement release valve

(20) Safety valve

FIgURE 1: Experimental set.

emulsion in various $\mathrm{W} / \mathrm{C}$ ratios via pressure into the dry mixture in various ratios placed in a cast.

According to Jaturapitakkul et al., in recent years, highstrength concrete has increasingly been used in civil engineering work because it has an advantage of reducing the sizes of beams and columns, which are essential in highrise buildings [2]. For this purpose, a prototype of machines for injection of bases was developed and used in concrete production. Successful results have been obtained in development of the prototype concrete injection device [3-10]. The developed device is given in Figure 1.

In Holland and his colleagues' research into attrition loss on the same kind of aggregate, control concrete with $\mathrm{W} / \mathrm{C}$ ratio of 0.45 had $6.9 \%$ attrition loss after 72 hours of attrition application. It was established that, under the same conditions, concrete that had silica fume as $17.6 \%$ of cement's volume and $\mathrm{W} / \mathrm{C}$ ratio of 0.53 had $5 \%$ and concrete that had silica fume as $42.9 \%$ of cement's volume and $\mathrm{W} / \mathrm{C}$ ratio of 0.21 had $2.2 \%$ of attrition loss [11]. According to Jahren, fresh concrete with silica fume additive decomposes less and has fewer settling cracks, while its adhesiveness is caused by the increase of its paste viscosity and density. Mineral additives that have high fineness prevent or substantially decrease perspiration in fresh concrete. Because the very high specific surface silica fume absorbs a part of free water, perspiration decreases [12]. Meland, in his research, has observed that silica fume added in $10 \%$ and $20 \%$ ratios in place of cement decreases the total hydrotation heat in the first two days [13]. According to Yeğinobalı, Sellevold, and Radj, silica fume particles in the state of small spheres improve granulometry and increase the amount of free water by exchanging places with water between the larger cement particles. Despite this positive effect, because of the very large silica fume particles total area to be moistened, the requirement for water increases in proportion to silica fume $[14,15]$. According to many researchers, the positive effect of silica fume additive to concrete's compressive strength is a result of strengthening aggregate-paste transition areas. On the other hand, it has been suggested that one of the most important factors is formation of compressed and high quality cement paste. Silica fume is an important element in improvement of concrete resistance. Silica fumes make concrete more resistant by blocking paste-aggregate transition areas [16-20].

\section{Materials and Experimental Program}

Concrete's mixture ratios prepared for compressive strength test are given in Table 1. Injection of binder with silica fume additive to the various control concrete given in Table 1 was based on the invariability of the binder emulsion's viscosity. The binder emulsion with cement and silica fume additive in various ratios was injected to dry mixture samples prepared 
TABLE 1: Ratios of concrete mixtures.

\begin{tabular}{|c|c|c|c|c|c|c|c|c|}
\hline \multirow{2}{*}{ Concrete groups } & \multicolumn{2}{|c|}{$\begin{array}{c}\text { Concrete mixed } \\
\text { water }\end{array}$} & \multirow{2}{*}{$\begin{array}{l}\text { Cement } \\
\left(\mathrm{kg} / \mathrm{m}^{3}\right)\end{array}$} & \multirow{2}{*}{$\begin{array}{l}\text { Silica } \\
\text { fume } \\
\left(\mathrm{kg} / \mathrm{m}^{3}\right)\end{array}$} & \multirow{2}{*}{$\begin{array}{c}\text { Fine } \\
\text { aggregate } \\
(\mathrm{kg}) \\
(0-4 \mathrm{~mm})\end{array}$} & \multirow{2}{*}{$\begin{array}{c}\text { Large } \\
\text { aggregate } \\
(\mathrm{kg}) \\
(4-16 \mathrm{~mm})\end{array}$} & \multicolumn{2}{|c|}{$\begin{array}{c}\text { Total } \\
\left(\mathrm{kg} / \mathrm{m}^{3}\right)\end{array}$} \\
\hline & $\begin{array}{l}\text { Normal } \\
\text { concrete }\end{array}$ & $\begin{array}{l}\text { Injected } \\
\text { concrete }\end{array}$ & & & & & $\begin{array}{c}\text { For } \\
\text { normal } \\
\text { concrete }\end{array}$ & $\begin{array}{c}\text { For } \\
\text { injected } \\
\text { concrete }\end{array}$ \\
\hline Control-30/70 & 212 & 280 & 400 & - & 520 & 1210 & 2342 & 2410 \\
\hline 30FS5 & 220 & 280 & 380 & 20 & 520 & 1210 & 2350 & 2410 \\
\hline $30 \mathrm{FS} 10$ & 228 & 280 & 360 & 40 & 520 & 1210 & 2358 & 2410 \\
\hline $30 F S 15$ & & 280 & 340 & 60 & 520 & 1210 & & 2410 \\
\hline $30 \mathrm{FS} 20$ & & 280 & 320 & 80 & 520 & 1210 & & 2410 \\
\hline Control-35/65 & 220 & 300 & 400 & - & 610 & 1120 & 2350 & 2430 \\
\hline 35FS5 & 232 & 300 & 380 & 20 & 610 & 1120 & 2362 & 2430 \\
\hline $35 \mathrm{FS} 10$ & 236 & 300 & 360 & 40 & 610 & 1120 & 2366 & 2430 \\
\hline $35 \mathrm{FS} 15$ & & 300 & 340 & 60 & 610 & 1120 & & 2430 \\
\hline $35 \mathrm{FS} 20$ & & 300 & 320 & 80 & 610 & 1120 & & 2430 \\
\hline Control-40/60 & 232 & 320 & 400 & - & 690 & 1040 & 2362 & 2450 \\
\hline $40 \mathrm{FS} 5$ & 240 & 320 & 380 & 20 & 690 & 1040 & 2370 & 2450 \\
\hline $40 \mathrm{FS} 10$ & 248 & 320 & 360 & 40 & 690 & 1040 & 2378 & 2450 \\
\hline 40FS15 & & 320 & 340 & 60 & 690 & 1040 & & 2450 \\
\hline 40FS20 & & 320 & 320 & 80 & 690 & 1040 & & 2450 \\
\hline
\end{tabular}

according to the experimental plan given in Table 2. 28 days later, compressive strength tests were done on injected samples and the changes in their properties were determined experimentally.

As described in Table 2, aggregates were first placed into cubic and cylindrical casts as dry mixtures in determined ratios by being compressed by skewers in three stages. After water and binding substance were prepared in determined ratios, they were gradually added to samples with the developed test device with 10 bar pressure. Samples' gross weights were determined before and after the injection. As described in the experiment plan given in Table 2, 6 samples were prepared for each property. After the prepared samples were kept in $90 \%$ relative humidity for a day, they were preserved in water at $23^{\circ} \mathrm{C}$ in the cure pool until the day of testing. After water and binding mixture (cement + emulsion with silica fume additive) were prepared by a mixer in a mixing container, they were poured into feeding tank with the help of a funnel, and 10 bar pressure was applied to all mixtures [21].

As is widely known, plaster's capillary water absorption and pressurized water permeability decrease with $\mathrm{W} / \mathrm{C}$ ratio, while its occupancy and unit weight increase. This increase is caused by decrease in amount and continuity of porosities in the structure and continues until a threshold level. When $\mathrm{W} / \mathrm{C}$ falls below this threshold value, the plaster does not get compressed enough, porosities increase, and as a result occupancy and unit weight drop, while capillary water absorption and pressurized water permeability increase. In order to keep this ratio stable in concrete samples, $\mathrm{W} / \mathrm{C}$ was taken as 0.70 , 0.75 , and 0.80 .

The test of concrete's compressive strength was conducted according to TS EN 12390-3. At the end of the 28th day and after resting for 24 hours, 6 samples were removed from the cure pool and weighed. Porosity $(P)$ and occupancy $(O)$ ratios of concrete are found with these formulas:

$$
\begin{gathered}
P=\frac{\left(W_{\text {sat }}-W_{\text {dry }}\right)}{\left(W_{\text {sat }}-W_{\text {wat }}\right)} \times 100, \\
O=1-P .
\end{gathered}
$$

The general properties of the other materials were as follows.

Cement. CEM I $42.5 \mathrm{~N}$ produced by Elazig Altınova Çimento Sanayi A.Ş. was used; chemical properties are given in Table 3.

Silica Fume. Silica fumes (FeSi) stored at Antalya Etibank Ferrokrom İşletmesi A.Ş. were used; their chemical properties are given in Table 3. In silica fume additive, weight was held constant and volume was variable.

Aggregate. Aggregate from Palu, Elazig was used. The largest particle size was $16 \mathrm{~mm}$; the chemical properties are given in Figure 1 and Table 4. Volume weights of pebbles in the most and least compressed states as determined by relative compression test were $\gamma_{\min }=1.625 \mathrm{~kg} / \mathrm{dm}^{3}$ and $\gamma_{\max }=$ $1.781 \mathrm{~kg} / \mathrm{dm}^{3}$.

Water. Tap water of Elazig city was used in tests.

Scale. A scale with $0.01 \mathrm{~g}$ precision was used.

Compressor. Pressure was received from the system connected to the current compressor. The maximum pressure of the compressor was 12 bars (Figure 1). 
TABLE 2: Basic properties of cement mixtures.

\begin{tabular}{|c|c|c|c|c|c|c|}
\hline Concrete groups & $\begin{array}{c}\text { Fine } \\
\text { aggregate }(\%) \\
(0-4 \mathrm{~mm})\end{array}$ & $\begin{array}{c}\text { Large } \\
\text { aggregate } \\
(\%) \\
(4-16 \mathrm{~mm})\end{array}$ & $\begin{array}{c}\text { Silica } \\
\text { fume } \\
(\%)\end{array}$ & $\begin{array}{l}\text { W/C ratio } \\
\text { for } \\
\text { normal } \\
\text { concrete }\end{array}$ & $\begin{array}{l}\mathrm{W} / \mathrm{C} \\
\text { ratio for } \\
\text { injection }\end{array}$ & $\begin{array}{c}\text { Injection } \\
\text { pressure } \\
\text { amount (bar) }\end{array}$ \\
\hline Control-30/70 & 30 & 70 & 0 & 0.53 & 0.70 & 10 \\
\hline $30 \mathrm{FS} 5$ & 30 & 70 & 5 & 0.55 & 0.70 & 10 \\
\hline $30 \mathrm{FS} 10$ & 30 & 70 & 10 & 0.57 & 0.70 & 10 \\
\hline $30 F S 15$ & 30 & 70 & 15 & 0.59 & 0.70 & 10 \\
\hline $30 \mathrm{FS} 20$ & 30 & 70 & 20 & 0.61 & 0.70 & 10 \\
\hline Control-35/65 & 35 & 65 & 0 & 0.55 & 0.75 & 10 \\
\hline $35 \mathrm{FS} 5$ & 35 & 65 & 5 & 0.58 & 0.75 & 10 \\
\hline $35 \mathrm{FS} 10$ & 35 & 65 & 10 & 0.59 & 0.75 & 10 \\
\hline $35 F S 15$ & 35 & 65 & 15 & 0.62 & 0.75 & 10 \\
\hline $35 \mathrm{FS} 20$ & 35 & 65 & 20 & 0.64 & 0.75 & 10 \\
\hline Control-40/60 & 40 & 60 & 0 & 0.58 & 0.80 & 10 \\
\hline $40 \mathrm{FS} 5$ & 40 & 60 & 5 & 0.60 & 0.80 & 10 \\
\hline $40 \mathrm{FS} 10$ & 40 & 60 & 10 & 0.62 & 0.80 & 10 \\
\hline $40 \mathrm{FS} 15$ & 40 & 60 & 15 & 0.65 & 0.80 & 10 \\
\hline 40FS20 & 40 & 60 & 20 & 0.68 & 0.80 & 10 \\
\hline
\end{tabular}

TABLE 3: Chemical analysis results of the cement and silica fume.

\begin{tabular}{lccccccccc}
\hline Content (\%) & $\mathrm{SiO}_{2}$ & $\mathrm{Al}_{2} \mathrm{O}_{3}$ & $\mathrm{Fe}_{2} \mathrm{O}_{3}$ & $\mathrm{MgO}$ & $\mathrm{CaO}$ & $\mathrm{Na}_{2} \mathrm{O}$ & $\mathrm{SO}_{3}$ & $\mathrm{~K}_{2} \mathrm{O}$ & $\mathrm{LOI}$ \\
\hline Cement & 20.55 & 4.60 & 3.20 & 2.95 & 63.10 & 0.73 & 2.40 & 0.26 & 2.21 \\
$\mathrm{FeSi}$ & 94.62 & 0.20 & 0.20 & - & 2.40 & 0.78 & 0.21 & 0.36 & 1.23 \\
\hline
\end{tabular}

TABLE 4: Physical properties of aggregate used in tests.

\begin{tabular}{|c|c|c|c|c|c|c|}
\hline \multirow{2}{*}{$\begin{array}{l}\text { Aggregate particle } \\
\text { class }\end{array}$} & \multirow{2}{*}{$\begin{array}{c}\text { Unit weight } \\
\text { (compressed) } \\
\left(\mathrm{kg} / \mathrm{m}^{3}\right)\end{array}$} & \multirow{2}{*}{$\begin{array}{c}\text { Specific weight } \\
(\mathrm{SSD}) \\
\left(\mathrm{kg} / \mathrm{m}^{3}\right)\end{array}$} & \multirow{2}{*}{$\begin{array}{c}\text { Water absorption } \\
(\%)\end{array}$} & \multirow{2}{*}{$\begin{array}{l}\text { Current } \\
\text { humidity } \\
\quad(\%)\end{array}$} & \multicolumn{2}{|c|}{$\begin{array}{l}\text { Attrition (\%) } \\
\text { (tüvenan) }\end{array}$} \\
\hline & & & & & $\begin{array}{l}100 \\
\text { rotations }\end{array}$ & $\begin{array}{l}500 \\
\text { rotations }\end{array}$ \\
\hline $0-4 \mathrm{~mm}$ & 1765 & 2.64 & 1.10 & 0.70 & - & - \\
\hline $4-16 \mathrm{~mm}$ & 1720 & 2.73 & 0.85 & 0.45 & 7.00 & 18.60 \\
\hline
\end{tabular}

Air Regulator-Manometer. An air regulator was used for adjusting the desired pressure and keeping it constant. The manometer was fixed above the regulator to control the applied pressure.

Hydraulic Hose. Hydraulic hosing was used for transferring air pressure to feeding tank and also cement mixture to the sample. Its compressive strength was $12 \mathrm{kpa}$.

Mixture Input Tank. Mixture input tank was the reduced version of the tank used in injection. The volume of the tank was 12 liters. The pressure input to the tank was done from the top by hoses and the cement mixture output was transferred by hydraulic hoses connected to the bottom of the tank. Valves were connected to these holes to control the flow.

Rigid Cap. A rigid cap was installed on the cubic and cylinder casts in the tests. There was a hole with $8 \mathrm{~mm}$ diameter at the center of the cap and a valve around it to release the compressed air. By not allowing vertical deformation, swelling of the samples was prevented and the outflow of the excess cement mixture was allowed during the injection. It was tightened from four directions with butterfly bolts to ensure rigidity.

Metal Thin Pipe. Metal thin pipe was used to inject cement mixture into the samples. The inner diameter of the pipe was $5 \mathrm{~mm}$ and there were 8 holes with $3 \mathrm{~mm}$ diameter at its end. Cement mixture was injected into samples from these holes and the pipe's end.

Concrete Sample Casts. In the tests, $10 \mathrm{~cm}$ cubic and standard cylinder 6 samples with $10 \mathrm{~cm}$ diameter and $20 \mathrm{~cm}$ height were used. The bottom sections of the casts were separable for removing the samples and their top sections were open. 
TABLE 5: Results of compressive strength of concrete groups (MPa).

\begin{tabular}{|c|c|c|c|c|}
\hline \multirow[b]{2}{*}{ Concrete groups } & \multicolumn{2}{|c|}{ Compressive strength } & \multicolumn{2}{|c|}{ Change ratios of compressive strength } \\
\hline & Normal concrete & Injected concrete & $\begin{array}{l}\text { Percentage of changes } \\
\text { in normal concrete } \\
\text { compared to control } \\
\text { concrete }\end{array}$ & $\begin{array}{l}\text { Percentage of changes } \\
\text { in injected concrete } \\
\text { compared to control } \\
\text { concrete }\end{array}$ \\
\hline Control-30/70 & 27.5 & 30.6 & 100 & 100 \\
\hline 30FS5 & 29.3 & 34.4 & 107 & 112 \\
\hline $30 \mathrm{FS} 10$ & 33.1 & 37.2 & 120 & 122 \\
\hline 30FS15 & 34.6 & 36.6 & 126 & 120 \\
\hline $30 \mathrm{FS} 20$ & 35.5 & 35.3 & 129 & 115 \\
\hline Control-35/65 & 26.6 & 29.4 & 100 & 100 \\
\hline 35FS5 & 28.7 & 33.2 & 108 & 113 \\
\hline $35 \mathrm{FS} 10$ & 32.2 & 36.1 & 121 & 123 \\
\hline $35 \mathrm{FS} 15$ & 33.9 & 35.4 & 127 & 120 \\
\hline $35 \mathrm{FS} 20$ & 34.3 & 35.1 & 129 & 119 \\
\hline Control-40/60 & 24.3 & 28.7 & 100 & 100 \\
\hline 40FS5 & 26.8 & 32.7 & 110 & 114 \\
\hline $40 \mathrm{FS} 10$ & 29.7 & 35.9 & 122 & 125 \\
\hline $40 \mathrm{FS} 15$ & 31.5 & 35.0 & 130 & 122 \\
\hline $40 \mathrm{FS} 20$ & 32.5 & 34.5 & 134 & 120 \\
\hline
\end{tabular}

Mixer. A standard laboratory concrete mixer machine with 1400 rotations/min, and as a mixing container, a steel container with $5 \mathrm{lt}$ volume was used [22, 23].

The Functioning System of the Experimental Set. As seen in Figure 1 [24], aggregate was prepared as a dry mixture. After being added to the casts in three layers, it was put in its place in the experimental apparatus and safety valve number 20 was turned on. Cement emulsion prepared in the desired W/C ratio was filled added tank number 8 . Pressurized air was transferred from tank number 4 until the manometer reads 10 bar pressure and then valve number 4 was turned off. The injection process was ended by turning valve number 9 off. Sudden injection was avoided in the process [20, 22-27].

\section{Results}

The percentage changes of compressive strength development of concrete with silica fume additive compared to control concrete are given in Table 5. Physical properties and measurements of porosity, occupancy, and compressive strength of concrete with silica fume additive produced by injection method are given in Figures 2 and 3.

In Figure 4, the relationship between silica fume $\%$ and occupancy is presented for concrete with fine aggregate ratios of 0.30 and large aggregate ratios of 0.70 . For the same aggregate ratios, the changes between silica fume additive $\%$ and development of compressive strength of concrete are given in Figure 5. From these experimental results, the following empirical relations are obtained:

$$
\begin{gathered}
\mathrm{OR}=-2 \mathrm{FS}^{2}+0.64 \mathrm{FS}+0.864, \quad R^{2}=0.9275 \\
\mathrm{CS}=-388.57 \mathrm{FS}^{2}+101.91 \mathrm{FS}+30.567, \quad R^{2}=0.9859 .
\end{gathered}
$$

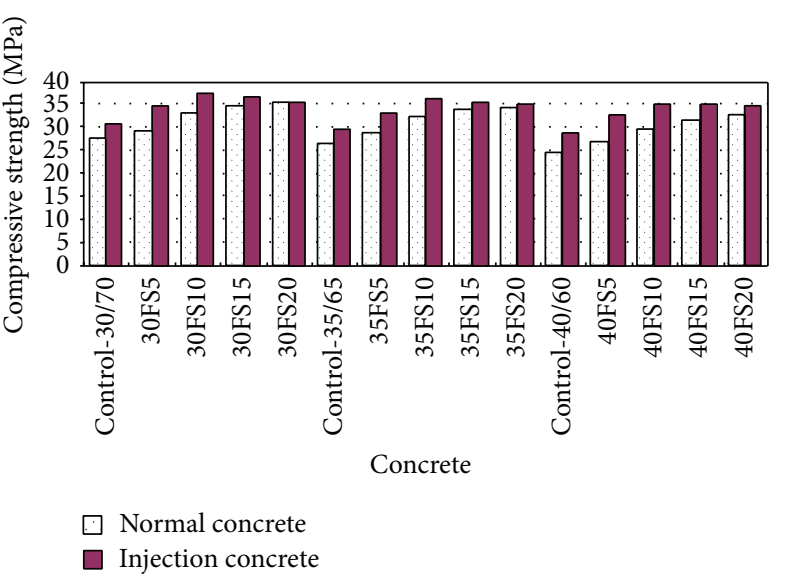

FIgURE 2: Compressive strength of concrete with silica fume additive.

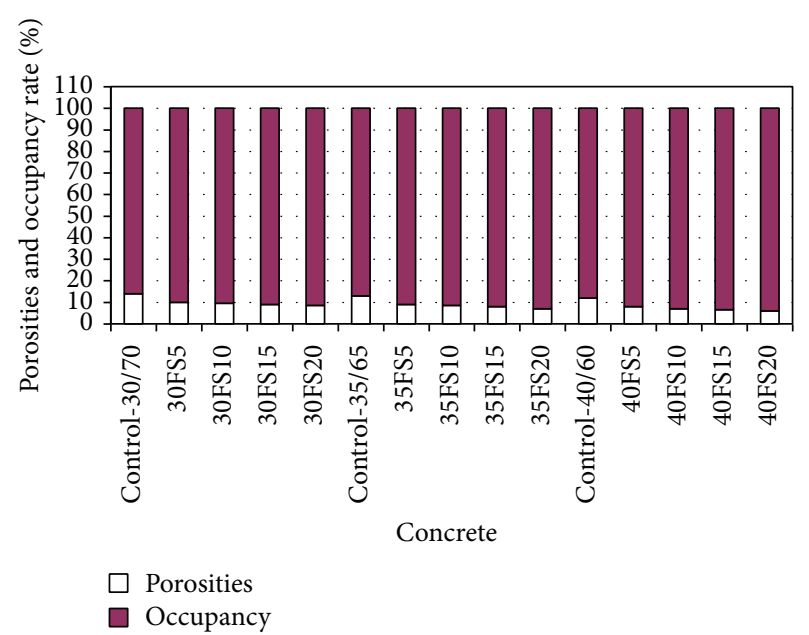

FIgURE 3: Porosity and occupancy ratios in concrete. 


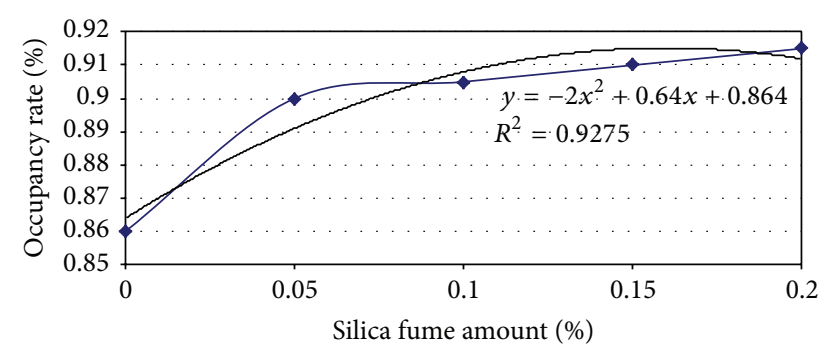

FIGURE 4: The relation between silica fume additive and occupancy in concrete with 30/70 fine/large aggregate ratios.

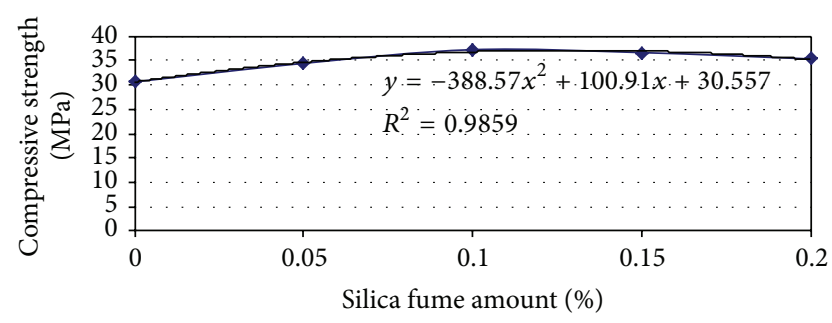

FIGURE 5: The relation between silica fume additive and compressive strength in concrete with 30/70 fine/large aggregate ratios.

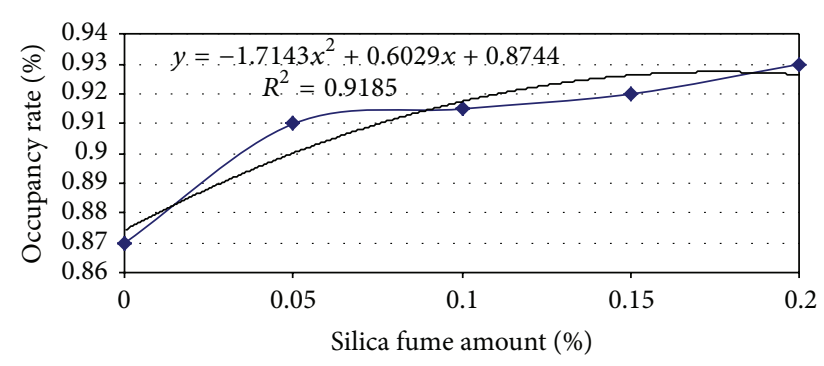

FIGURE 6: The relation between silica fume additive and occupancy in concrete with 35/65 fine/large aggregate ratios.

As seen in Figures 4, 6, and 8, up to $10 \%$ silica fume additive, concrete's compressive strength, and occupancy ratios increased constantly. However, in injected concrete, more than $10 \%$ of silica fume additive increases occupancy but not the compressive strength. The use of more than $10 \%$ silica fume in concrete is weak the aggregate-mortar transition region in all concrete. In addition, the workability of concrete is affected negatively.

In Figure 6, the change between silica fume $\%$ and occupancy is presented for concrete with fine aggregate ratio of 0.35 and large aggregate ratio of 0.65 . For the same aggregate ratios, the changes between silica fume additive $\%$ and development of compressive strength of concrete are given in Figure 7. From these experimental results, the following empirical relations are obtained:

$$
\begin{aligned}
& \mathrm{OR}=-1.7143 \mathrm{FS}^{2}+0.6029 \mathrm{FS}+0.8744, \quad R^{2}=0.9185, \\
& \mathrm{CS}=-337.14 \mathrm{FS}^{2}+94.629 \mathrm{FS}+29.434, \quad R^{2}=0.9723 .
\end{aligned}
$$

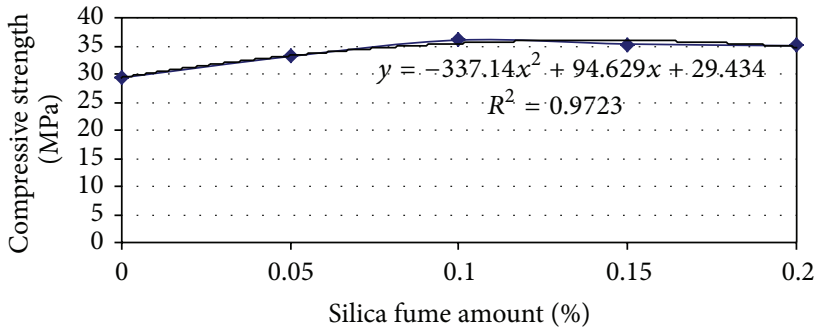

FIGURE 7: The relation between silica fume additive and compressive strength in concrete with 35/65 fine/large aggregate ratios.

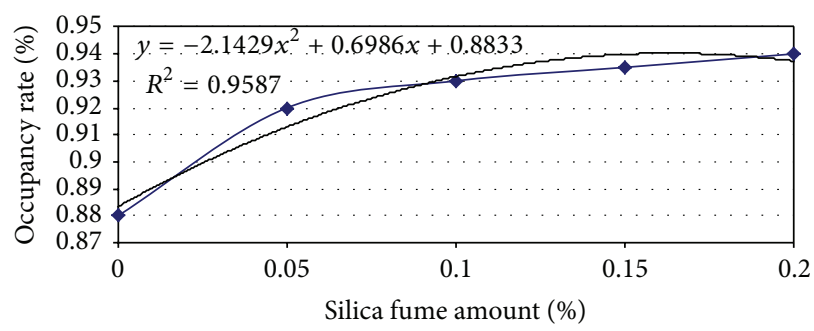

FIgURE 8: The relation between silica fume additive and occupancy in concrete with 40/60 fine/large aggregate ratios.

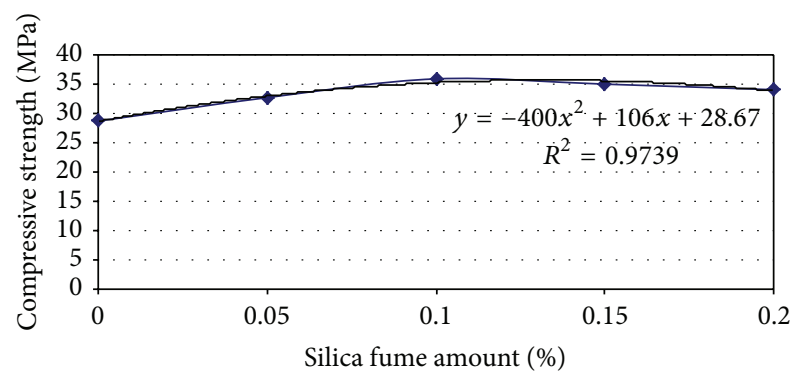

FIGURE 9: The relation between silica fume additive and compressive strength in concrete with 40/60 fine/large aggregate ratios.

As seen in figures, up to $10 \%$ silica fume additive, concrete's compressive strength, and occupancy ratios increased constantly. However, in injected concrete, more than $10 \%$ of silica fume additive increased occupancy but not the compressive strength.

In Figure 8 , the change between silica fume $\%$ and occupancy is presented for concrete with fine aggregate ratio of 0.40 and large aggregate ratio of 0.60 . For the same aggregate ratios, the changes between silica fume additive $\%$ and development of compressive strength of concrete are given in Figure 9. From these experimental results, the following empirical relations are obtained:

$$
\begin{gathered}
\mathrm{OR}=-2.1429 \mathrm{FS}^{2}+0.6986 \mathrm{FS}+0.8833, \quad R^{2}=0.9587 \\
\mathrm{CS}=-400 \mathrm{FS}^{2}+106 \mathrm{FS}+28.67, \quad R^{2}=0.9739
\end{gathered}
$$

As seen in figures, up to $10 \%$ silica fume additive, concrete's compressive strength, and occupancy ratios increased 
constantly in the positive direction. However, in injected concrete, more than $10 \%$ of silica fume additive increased occupancy but not the compressive strength.

\section{Conclusions and Suggestions}

FeSi based silica fume additive affected concrete's compressive strength in the positive direction up to $10 \%$ of the weight of the cement produced by injection method. The highest compressive strength was in concrete with $10 \%$ silica fume additive and $40 \%$ fine aggregate. An increase in occupancy ratio and decrease in porosity ratio can explain this result. Addition of $10 \%$ or more silica fume to the pretest mixtures requires very high $\mathrm{W} / \mathrm{C}$ ratio for injection. When more than $10 \%$ silica fume was added and the fine material ratio was increased, compressive strength of concrete dropped. In large sectional porosities in the control concrete, smaller porosities are formed due to the present use of silica fume and the increase of fine aggregate ratio. Detachment of aggregates from the concrete occurred via more aggregates coming off and/or their breaking out from their sockets. As silica fume and fine material ratios increased, detachments of aggregates occurred as a result of aggregates breaking in the middle.

\section{Nomenclature}

$\begin{array}{ll}\text { OR: } & \text { Occupancy rate equal } \\ \text { CS: } & \text { Compressive strength equal } \\ R^{2}: & \text { Fault rate } \\ \text { FS: } & \text { Silica fume (FeSi) } \\ \text { Control-30/70: } & \text { Control concrete with 30\% fine aggregate } \\ & +70 \% \text { coarge aggregate } \\ \text { 30FS5: } & \text { Concrete with \%30 fine aggregate and 5\% } \\ & \text { FeSi silica fume } \\ \text { W/C: } & \text { Water cement rate } \\ P: & \text { Vacuum saturation porosity (\%) } \\ O: & \text { Occupancy (composite) } \\ W_{\text {sat }}: & \text { Weight in air of saturated sample } \\ W_{\mathrm{dry}}: & \text { Weight of oven-dried sample } \\ W_{\text {wat }}: & \text { Weight in water of saturated sample } \\ \text { SSD: } & \text { Saturated surface dry. }\end{array}$

\section{Conflict of Interests}

The authors declare that they have no conflict of interests.

\section{References}

[1] S. Bhanja and B. Sengupta, "Influence of silica fume on the tensile strength of concrete," Cement and Concrete Research, vol. 35, no. 4, pp. 743-747, 2005.

[2] C. Jaturapitakkul, K. Kiattikomol, V. Sata, and T. Leekeeratikul, "Use of ground coarse fly ash as a replacement of condensed silica fume in producing high-strength concrete," Cement and Concrete Research, vol. 34, no. 4, pp. 549-555, 2004.

[3] I. Ceran, Injection of bases and laboratory injection experiments [M.S. thesis], Istanbul Technical University, Istanbul, Turkey, 1990.
[4] M. Incecik and A. Senol, "Recent developments in cement injection," Journal of Istanbul Technical University, vol. 52, pp. 61-69, 1994.

[5] A. Ozocak, Injection model experiments with fine grained cement [M.S. thesis], Istanbul Technical University, Istanbul, Turkey, 1994.

[6] N. Su and Y.-N. Peng, "The characteristics and engineering properties of dry-mix/steam-injection concrete," Cement and Concrete Research, vol. 31, no. 4, pp. 609-619, 2001.

[7] C. E. Ekinci, "The calculation methods of compound of concrete and a novel calculation method," E-Journal of New World Sciences Academy, vol. 1, no. 1, pp. 1-12, 2006.

[8] S. Sawada, C. L. Page, and M. M. Page, "Electrochemical injection of organic corrosion inhibitors into concrete," Corrosion Science, vol. 47, no. 8, pp. 2063-2078, 2005.

[9] C. E. Ekinci, Burgundy Book: Structure and Designer's Construction Handbook, Universite Kitabevi, Elazig, Turkey, 2008.

[10] A. Çatal, Geo-Technical Applications in Atatürk Dam, Atak Ofset, Ankara, Turkey, 1993.

[11] T. C. Holland, A. Krysa, M. D. Luthet, and T. C. Liu, "Use of silica-fume concrete to repair abrasion-erosion damage in the Kinzua Dam Stilling Basin," in Proceedings of the CANMET/ACI International Conference on Fly Ash, Silica Fume, Slag and Natural Pozzolans in Concrete, vol. 91, no. 2, pp. 841-863, 1986.

[12] P. Jahren, "Use of silica fume in concrete," in Proceedings of the CANMET/ACI International Conference on Fly Ash, Silica Fume, Slag and Natural Pozzolans in Concrete, no. 1, pp. 625-642, 1983.

[13] I. Meland, "Influence of condensed silica fume and fly ash on the heat evolution in cement pastes," in Proceedings of the 1st CANMET/ACI International Conference on Fly Ash, Silica Fume, Slag and Natural Pozzolans in Concrete, vol. 79, no. 1, pp. 665676, 1983.

[14] M. A. Yeğinobalı, "Evaluation of silica fume as an additive in concrete," in Symposium of the Use of Industrial Solid Wastes in Construction Sector, pp. 149-167, Bogazici University, Istanbul, Turkey, 1993.

[15] E. J. Sellevold and F. F. Radj, "Condensed silica fume (mikrosilica) in concrete: water and strength development," in Proceedings of the 2nd CANMET/ACI International Conference on Fly Ash, Silica Fume, Slag and Natural Pozzolans in Concrete, vol. 132, no. 1, pp. 677-694, 1983.

[16] C. E. Ekinci, Potential uses of Silica fumes from antalya etibank elektrometalurji industry as admixtures in Cement and Concrete [Ph.D. thesis], Firat University, Elazig, Turkey, 1995.

[17] O. E. Grojy, "Durability of concrete containing condensed silica fume," in Proceedings of the 1st International Conference on the Use of Fly Ash, Silica Fume, Slag and Other Mineral by Products in Concrete, no. 1, pp. 695-708, 1983.

[18] A. Goldman and A. Bentur, "Bond effects in high-strength silica-fume concretes," ACI Materials Journal, vol. 86, no. 5, pp. 440-447, 1989.

[19] V. M. Malhotra, G. G. Carette, and V. Sivasundaram, "Role of silica fume in concrete: a review," in Proceedings of the Symposium on Advanced in Concrete Technology, Athens, Greece, 1992.

[20] P.-C. Aitcin, V. M. Malhotra, G. G. Carette, M. F. Pistilli, and J. T. Wolsiefer, "Silica fume in concrete," ACI Materials Journal, vol. 84, no. 2, pp. 158-166, 1987.

[21] C. E. Ekinci and M. Ersimsek, "The research of physical properties of concrete which is containing granular ferrokrom slag which is produced by using the method of injection," $E$ Journal of New World Sciences Academy, vol. 1, no. 3, pp. 67-74, 2006. 
[22] TS3530 prEN 933-1, “Tests for Geometrical Properties of Aggregates Part 1: Determination of Particle Size DistributionGranulometric Analysis (Sieving Method)," Turkish Standard Institute (Turkish Codes), Ankara, Turkey, 1997, (Turkish).

[23] TS706 EN 12620, "Aggregates for Concrete," Turkish Standard Institute (Turkish Codes), Ankara, Turkey, 2009, (Turkish).

[24] M. Ersimsek, Investigation of the physical features of the concrete which contains the slag of granule ferrochrome produced by injection method [M.S. thesis], Firat University, Elazig, Turkey, 2006.

[25] TS3068 ISO2736, "Preparation and Maintenance of Experiment Samples in Laboratory," Turkish Standard Institute (Turkish Codes), Ankara, Turkey, 1999, (Turkish).

[26] TSEN 12390-3, “Testing Hardened Concrete-Part 3: Compressive Strength of Test Specimens," Turkish Standard Institute (Turkish Codes), Ankara, Turkey, 2003, (Turkish).

[27] TS3529 ISO6782, "Test Method for Determination of the Unit Weight of Aggregates for Concrete," Turkish Standard Institute (Turkish Codes), Ankara, Turkey, 2009 (Turkish). 

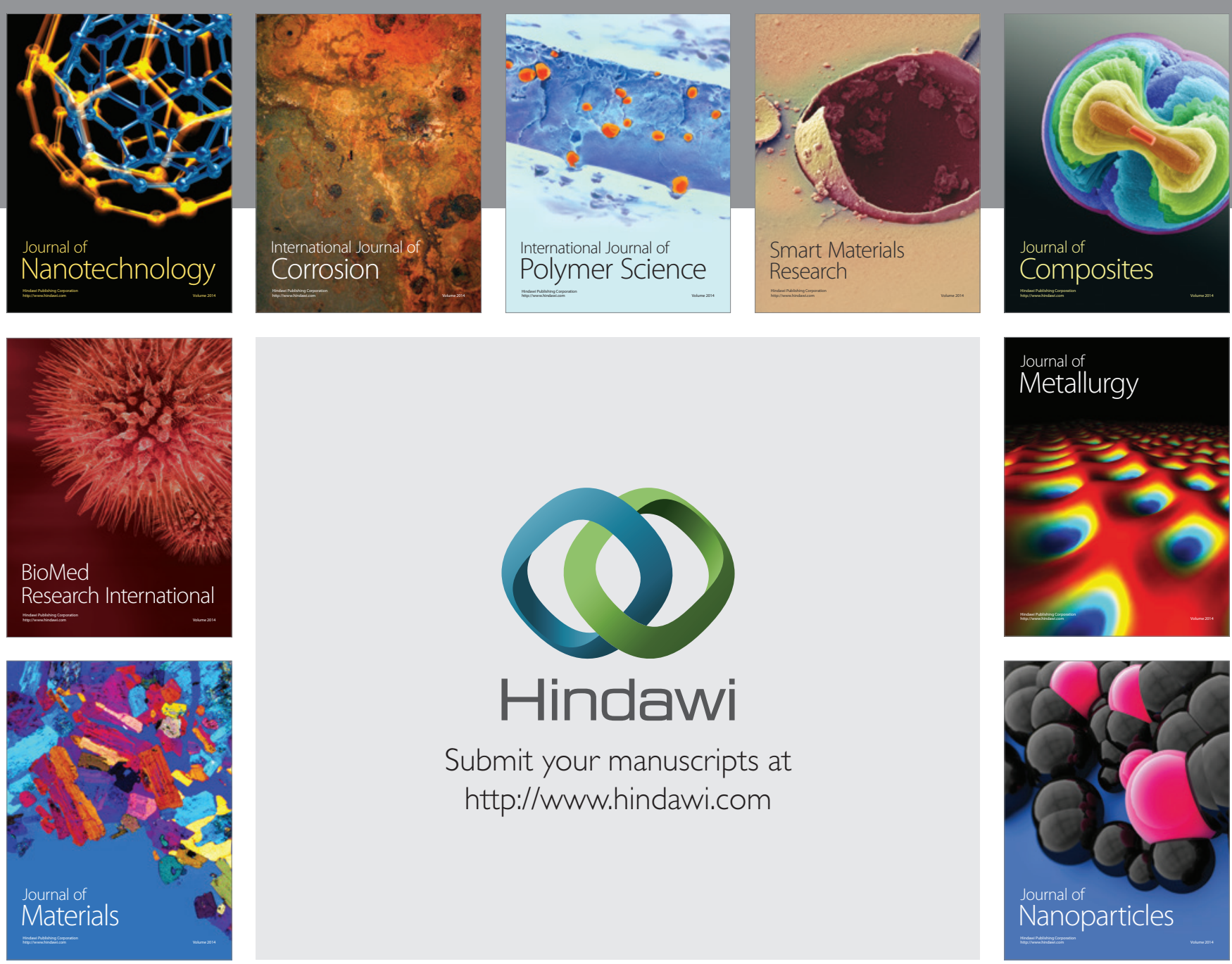

Submit your manuscripts at http://www.hindawi.com
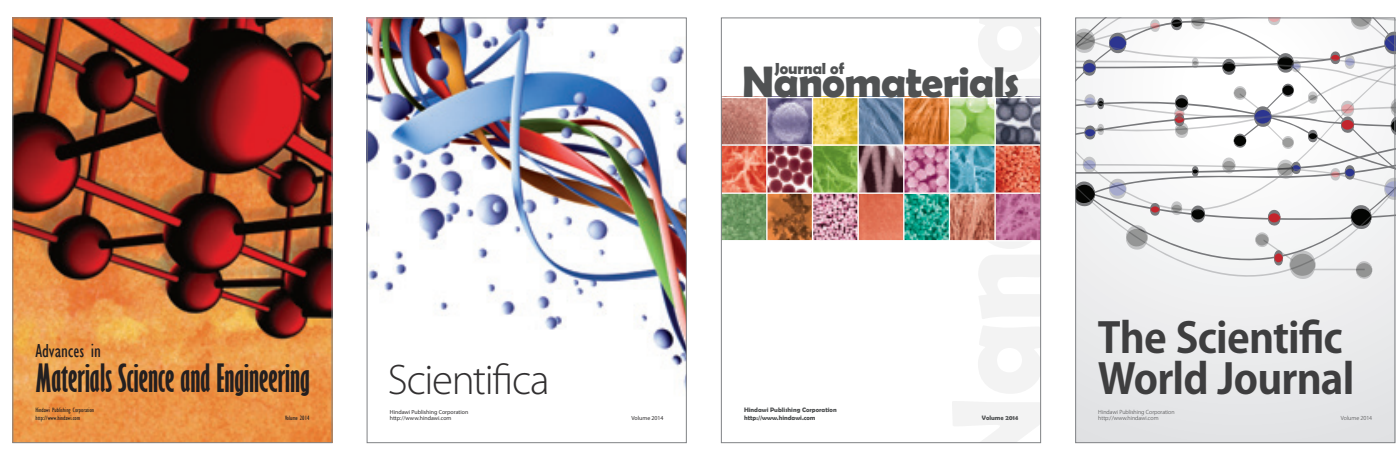

\section{The Scientific World Journal}
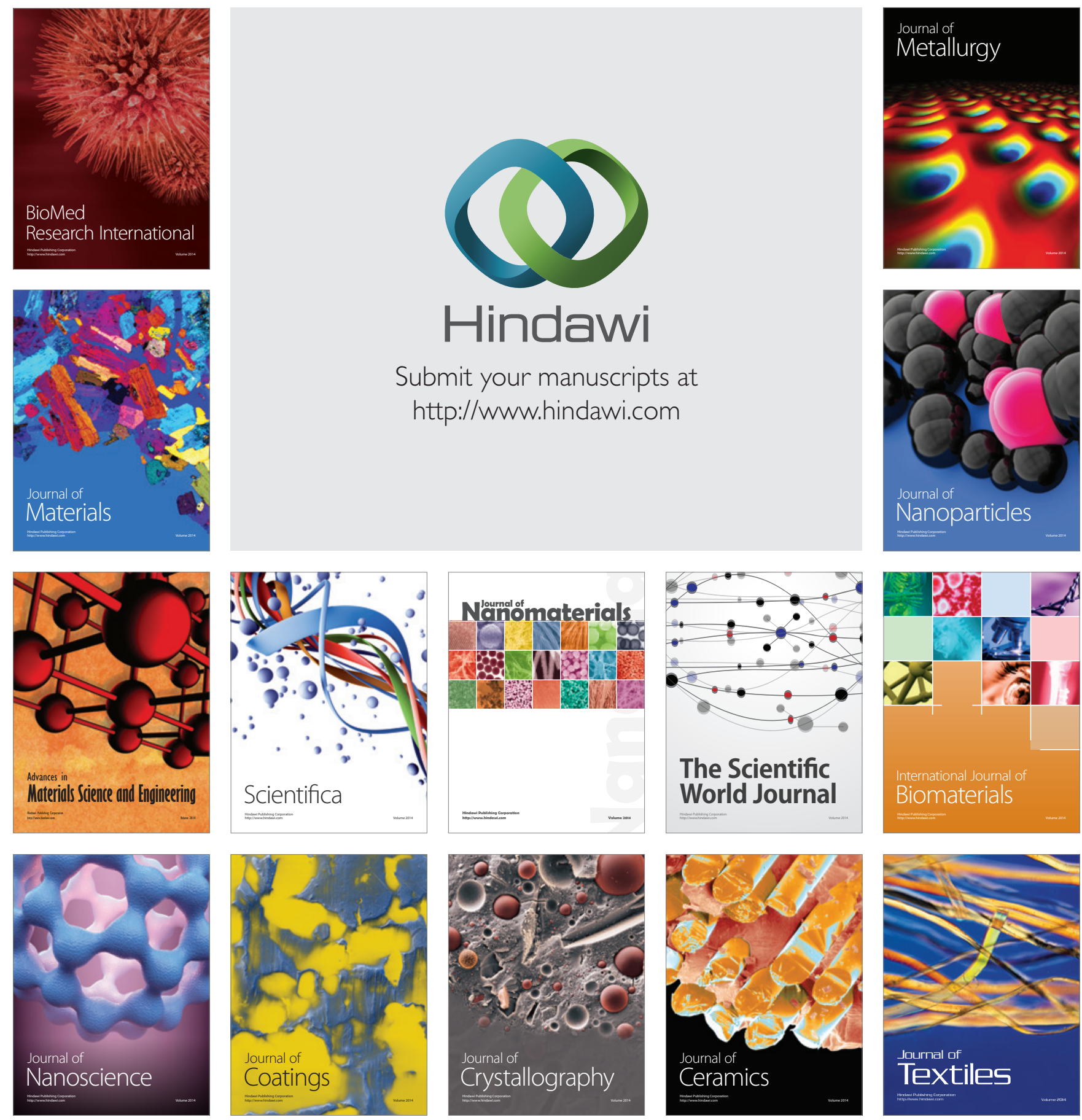